\title{
Physicochemical and sensory characteristics of biscuits from corn flour (Zea mays) with orange sweet potato flour (Ipomoea batatas L.)
}

\author{
Riffa Sinulingga ${ }^{1}$, and Sentosa Ginting ${ }^{1, *}$ \\ ${ }^{1}$ Department of Food Science and Technology, Faculty of Agriculture, USU, 20155, Medan, \\ Indonesia
}

\begin{abstract}
This study was carried out to investigate the physicochemical and sensory characteristics of biscuits as affected by the ratio of corn flour $(\mathrm{CF})$ and orange sweet potato flour (OSPF). Six samples of biscuits were made from $\mathrm{CF}$ and OSPF in various ratio namely $\mathrm{P}_{1}\left(100 \%\right.$ corn flour), $\mathrm{P}_{2}$ (80:20), $\mathrm{P}_{3}$ (60:40), $\mathrm{P}_{4}$ (40:60), $\mathrm{P}_{5}(20: 80), \mathrm{P}_{6}(100 \%$ OSP flour), and one sample as control namely $\mathrm{P}_{7}(100 \%$ wheat flour). The results showed that the ratio of CF and OSPF had a very significant effect $(\mathrm{P}<0.01)$ specific volume, hardness, water absorption, ash content, protein content, fat content, carbohydrate content, and crude fiber content of biscuits. The biscuits most acceptable by consumers were produced from $80 \%$ CF with $20 \%$ OSPF.
\end{abstract}

\section{Introduction}

Biscuit is one of the snacks processed using wheat flour (WF) and added other food ingredients. Biscuits are a popular food in the community and very practical because they can be consumed anywhere and anytime. Many types of biscuits have been reproduced to produce biscuits that are not only delicious, but also healthy for consumption [1].

Hibrida variety corn is used for food only around $30 \%$, the rest is used for animal feed, industry, and seeds. This can be used as an opportunity to develop this material into processed foods. In addition, this Hibrida variety corn is no less superior to wheat; this corn contains elements of Fe, dietary fiber, and beta-carotene (pro-vitamin A) so that it can be used as processed food. Corn will be more durable and practical if corn is in the form of flour and can be fortified or enriched with nutrients [2]. Corn flour (CF) is suitable for manufacturing foods that do not require ingredients with high gluten content, such as pastries so that $\mathrm{CF}$ can be used because it has less than $1 \%$ gluten. Biscuits are a type of snack that many people like, so they can be an opportunity to replace WF [3].

*Corresponding author: sentosa.ginting@,usu.ac.id 
Sweet potatoes contain high carbohydrates, so they play a vital role in overcoming malnutrition. Orange sweet potatoes (OSP) are among the most commonly known. (OSP) has a high sugar content, the flesh of the tuber is solid after cooking and has a good texture. OSP has B vitamins and vitamin $\mathrm{C}$ and has high beta-carotene [4]. Like tubers in general, OSP also has a relatively short shelf life and spoil quickly because of their high water content. Therefore, it is necessary to process OSP into specific products, for example, processing into flour. One of the products that can utilize orange sweet potato flour (OSPF) is biscuits.

\section{Material and Methods}

\subsection{Preparation of CF}

Corn that has been harvested is cleaned or separated from the skin and dried in the sun to dry with a maximum moisture content of $14 \%$. After that, the corn kernels are separated from the corn cobs and mashed using a corn grinding machine, then the resulting flour is sifted through a 60 mesh sieve.

\subsection{Preparation of OSPF}

First, clean the OSP, peeled, and then thinly sliced (2 $\mathrm{mm}$ thickness). Next soaked in $2000 \mathrm{ppm}$ sodium metabisulphite solution for 15 minutes. Tread slices were washed and dried in drying oven with $55{ }^{\circ} \mathrm{C}$ temperature for 12 hours. The dried slices were milled using a 80 mesh sieve.

\subsection{Preparation Biscuits}

The methods by Limanto et al. [5] with some modification was used. The ratio of CF and OSPF was written in Table 1. Sample were weighed based on $100 \mathrm{~g}$ of flour and the ingredient for each bread were shown in Table 1. First, mix shortening and powdered sugar were mixed until homogeneous and form a cream, then mix dry ingredients such as flour, salt, and baking powder and mix on low speed and add water according to the formula until the dough is smooth. Then the dough was made into sheets using pasta maker with a thickness of $3 \mathrm{~mm}$ and molded into circles with a diameter of $4 \mathrm{~cm}$, were greased with margarine and laid out on top, then the dough is baked in an oven that has been preheated to a temperature of $150{ }^{\circ} \mathrm{C}$ for 15 minutes. After baking, the biscuits were cooled at room temperature for 30 minutes, then packed into airtight polyethylene plastic for 24 hours for further analysis.

Table 1. Ingredients used in various treatment of biscuits.

\begin{tabular}{|c|c|c|c|c|c|c|c|}
\hline Ingredient $(\mathrm{g})$ & $\mathrm{P}_{1}$ & $\mathrm{P}_{2}$ & $\mathrm{P}_{3}$ & $\mathrm{P}_{4}$ & $\mathrm{P}_{5}$ & $\mathrm{P}_{6}$ & $\mathrm{P}_{7}$ \\
\hline Corn flour/CF (g) & 100 & 80 & 60 & 40 & 20 & 0 & 0 \\
\hline Orange sweet potato flour/OSPF (g) & 0 & 20 & 40 & 60 & 80 & 100 & 0 \\
\hline Wheat flour/WF (g) & 0 & 0 & 0 & 0 & 0 & 0 & 100 \\
\hline Refined sugar (g) & 30 & 30 & 30 & 30 & 30 & 30 & 30 \\
\hline Baking powder (g) & 1.5 & 1.5 & 1.5 & 1.5 & 1.5 & 1.5 & 1.5 \\
\hline Shortening (g) & 50 & 50 & 50 & 50 & 50 & 50 & 50 \\
\hline Salt (g) & 0.5 & 0.5 & 0.5 & 0.5 & 0.5 & 0.5 & 0.5 \\
\hline Water (mL) & 20 & 20 & 20 & 20 & 20 & 20 & 20 \\
\hline
\end{tabular}




\subsection{Analysis of biscuits quality}

The specific volume of biscuits was analyzed by seed replacement test according to the approve method by Yananta [6]. The hardness of biscuits was analyzed by hardness tester. The water absorption of biscuits was measured according to the approve method by Sathe and Salunkhe [7]. The water, protein and fat content of biscuits was measured according to the approve method by AOAC [8]. The ash content of biscuits was measured according to the approve method by Sudarmadji [9]. The crude fiber content of biscuits measured according to the approve method by Apriyantono et al. [10].

The carbohydrate content of biscuits was analyzed by difference method, namely by calculating the water content, ash content, protein content and fat content. The following is the equation used in calculating carbohydrate content using the by difference method.

Carbohydrate content $(\%)=100 \%-(\%$ water content $+\%$ ash content $+\%$ protein content $+\%$ fat content)

The sensory characteristics was analyzed using hedonic scale on 7 points $(1=$ dislike highly, $2=$ dislike, $3=$ quite dislike, $4=$ neither like nor dislike, $5=$ quite like, $6=$ like, $7=$ like highly) by 30 semi trained panelists both genders from students Department of Food Science and Technology, Faculty of Agriculture USU. Biscuits were identified by a three digits random number. The sample was offered to the panelists on a white plate at room temperature and drinking water provided. Panelists was asked to evaluate the color, odor, taste, texture, and overall acceptability of the biscuits.

\subsection{Data analysis}

The research was performed using a non-factorial completely randomized design, namely the ratio of CF and OSPF in biscuits formulation. Data was subjected to analysis of variance (ANOVA) using SPSS version 22.0. If the results are significantly different and very significant, then the test is continued with the mean difference test using the Least Significant Range (LSR) test.

\section{Result and Discussion}

\subsection{Quality of CF and OSPF}

$\mathrm{CF}$ and orange OSPF that have been researched including water absorption, protein content, fat content, carbohydrate content, and crude fiber content as shown in Table 2.

Table 2. Quality of CF and OSPF

\begin{tabular}{|c|c|c|c|}
\hline Parameter & $\begin{array}{c}\text { Corn flour/ } \\
\text { CF }\end{array}$ & $\begin{array}{c}\text { Orange sweet } \\
\text { potato flour/OSPF }\end{array}$ & $\begin{array}{c}\text { Wheat flour/ } \\
\text { WF }\end{array}$ \\
\hline Water absorption $(\mathrm{g} / \mathrm{g})$ & 2.91 & 3.01 & - \\
\hline Protein content $(\%)$ & 7.30 & 4.44 & $11.80^{*}$ \\
\hline Fat content $(\%)$ & 3.67 & 0.94 & $1.20^{*}$ \\
\hline Carbohydrate content (\%) & 78.51 & 86.41 & $74.50^{*}$ \\
\hline Crude fiber content $(\%)$ & 3.58 & 4.22 & $0.50^{* *}$ \\
\hline
\end{tabular}

Figures in table mean of 3 replicates, \pm standard deviation.

*Kent, 1983; **Ardiyanti, 2001.

The quality of corn flour and orange sweet potato flour needs to be known to see the processing and treatment that is determined on the quality of the biscuits produced. 


\subsection{Effect of blending ratio of CF and OSPF on physical quality of biscuits}

The results showed that ratio of CF and OSPF had effect to physical quality of biscuits as shown in Table 3.

Table 3. Effect of blending ratio of CF and OSPF on physical quality of biscuits.

\begin{tabular}{|c|c|c|c|}
\hline $\begin{array}{c}\text { Ratio of CF and } \\
\text { OSPF }(\mathrm{P})\end{array}$ & $\begin{array}{c}\text { Specific volume } \\
(\mathrm{mL} / \mathrm{g})\end{array}$ & $\begin{array}{c}\text { Hardness } \\
\left(\mathrm{kg} / \mathrm{cm}^{2}\right)\end{array}$ & $\begin{array}{c}\text { Water absorption } \\
(\mathrm{g} / \mathrm{g})\end{array}$ \\
\hline $\mathrm{P}_{1}$ & $1.51 \pm 0.03^{\mathrm{b}, \mathrm{B}}$ & $4.75 \pm 0.29^{\mathrm{a}, \mathrm{A}}$ & $1.51 \pm 0.07^{\mathrm{a}, \mathrm{AB}}$ \\
\hline $\mathrm{P}_{2}$ & $1.58 \pm 0.04^{\mathrm{b}, \mathrm{B}}$ & $3.90 \pm 0.29^{\mathrm{b}, \mathrm{BC}}$ & $1.49 \pm 0.02^{\mathrm{a}, \mathrm{AB}}$ \\
\hline $\mathrm{P}_{3}$ & $1.51 \pm 0.15^{\mathrm{b}, \mathrm{B}}$ & $4.24 \pm 0.29^{\mathrm{ab}, \mathrm{AB}}$ & $1.46 \pm 0.12^{\mathrm{a}, \mathrm{ABC}}$ \\
\hline $\mathrm{P}_{4}$ & $1.58 \pm 0.09^{\mathrm{b}, \mathrm{B}}$ & $3.90 \pm 0.29^{\mathrm{b}, \mathrm{BC}}$ & $1.55 \pm 0.11^{\mathrm{a}, \mathrm{A}}$ \\
\hline $\mathrm{P}_{5}$ & $1.62 \pm 0.14^{\mathrm{b}, \mathrm{B}}$ & $4.24 \pm 0.29^{\mathrm{ab}, \mathrm{AB}}$ & $1.31 \pm 0.03^{\mathrm{b}, \mathrm{BCD}}$ \\
\hline $\mathrm{P}_{6}$ & $1.52 \pm 0.08^{\mathrm{b}, \mathrm{B}}$ & $3.73 \pm 0.29^{\mathrm{bc}, \mathrm{BC}}$ & $1.26 \pm 0.06^{\mathrm{b}, \mathrm{CD}}$ \\
\hline $\mathrm{P}_{7}$ & $2.14 \pm 0.11^{\mathrm{a}, \mathrm{A}}$ & $3.22 \pm 0.29^{\mathrm{c}, \mathrm{C}}$ & $1.21 \pm 0.08^{\mathrm{b}, \mathrm{D}}$ \\
\hline
\end{tabular}

Figures in table mean of 3 replicates, \pm standard deviation. Numbers followed by different letters in the same column show significantly different effects at the 5\% level (lowercase letter) and very significant differences at the $1 \%$ level (capital letter) with the LSR test.

Table 3 shows the comparison of CF biscuits with OSPF in each treatment $\mathrm{P}_{1}$ to $\mathrm{P}_{6}$ which was very significantly different from $P_{7}$. This is because $P_{7}$ biscuits are made from $100 \% \mathrm{WF}$, WF contains gluten which can absorb a little water so that it forms a structure to trap air in order to increase the volume of dough in food making [10]. Biscuits with treatments $\mathrm{P}_{1}$ to $\mathrm{P}_{6}$ were not significantly different and had the lowest specific volume value in treatments $\mathrm{P}_{1}$ and $\mathrm{P}_{3}$, namely $1.51 \mathrm{ml} / \mathrm{g}$. This is because there is no addition of WF so that there is no gluten in it and causes the product to not expand or increase in volume. The relationship between flour ratio with biscuit spesific volume can be seen in Figure 1.

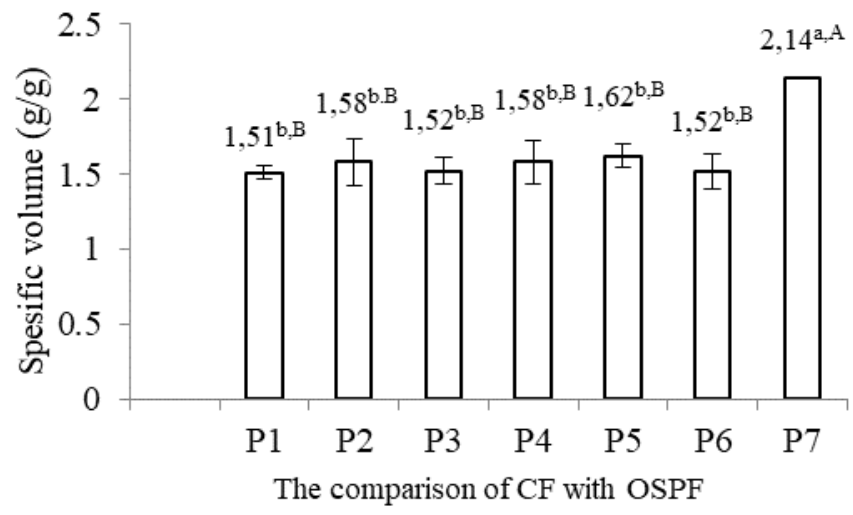

Fig 1. The relationship between flour ratio with biscuit spesific volume

The comparison of CF with OSPF in table 3 is very significantly different where the lowest hardness value is $3.22 \mathrm{~kg} / \mathrm{cm}^{2}$ in treatment $\mathrm{P}_{7}(100 \% \mathrm{WF})$ which means the texture of $\mathrm{P}_{7}$ biscuits is less hard than other treatments. WF that contains gluten is able to form a cell wall structure that produces crumb products. This specific property is not processed by $\mathrm{CF}$ and OSPF so that the resulting biscuit product has a higher hardness value as in the treatment $\mathrm{P}_{1}(100 \% \mathrm{CF})$ and $\mathrm{P}_{6}\left(100 \%\right.$ OSPF) which has a hardness value of $3.73 \mathrm{~kg} / \mathrm{cm}^{2}$ 
and $4.75 \mathrm{~kg} / \mathrm{cm}^{2}$. It can be seen that $\mathrm{CF}$ has higher amylose content $(33.10 \%)$ when compared to OSPF $(22.9 \%)$ [11]. The relationship between flour ratio with biscuit hardness can be seen in Figure 2.

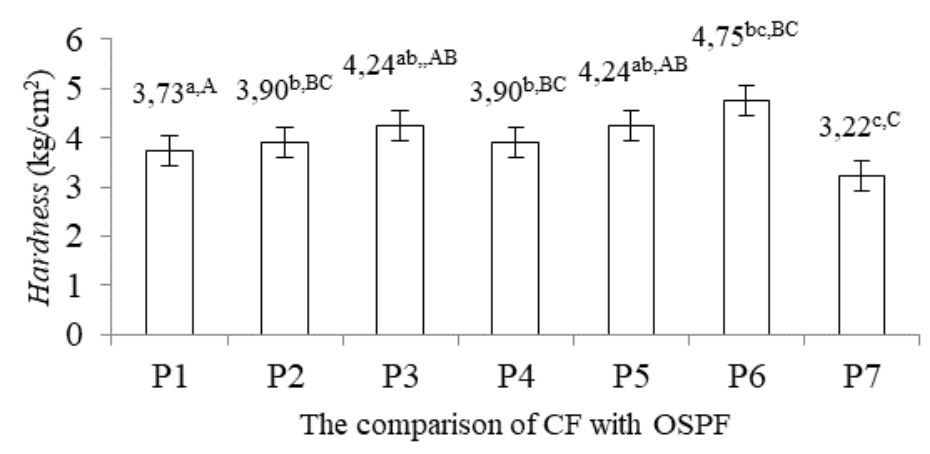

Fig 2. The relationship between flour ratio with biscuit hardness

Table 3 shows the comparison of CF with OSPF has a very significant effect on the water absorption of biscuits. The highest water absorption in treatment $\mathrm{P}_{4}(40 \% \mathrm{CF}: 60 \%$ OSPF) was $1.55 \mathrm{~g}$ and the lowest water absorption in treatment $\mathrm{P}_{7}$. This result was due to the higher amylose content of CF (33.10\%) and OSPF (22.9\%) than WF (20\%). \%). This is in accordance with the literature of Kusnandar [12], which states that the higher the amount of amylose in flour, the water absorption of flour will also be higher, besides that the presence of protein also increases water absorption because it is easy to absorb water. The relationship between flour ratio with biscuit water absorption can be seen in Figure 3 .

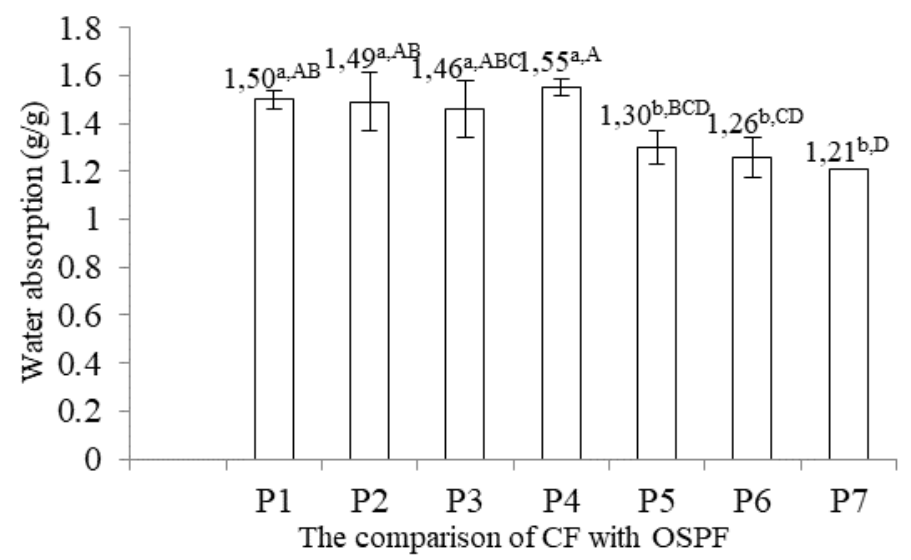

Fig 3. The relationship between flour ratio with biscuit water absorption 


\subsection{Effect of blending ratio of CF and OSPF on chemical quality of biscuits}

The results showed that ratio of CF and OSPF had effect to chemical quality of biscuits as shown in Table 4.

Table 4. Effect of blending ratio of CF and OSPF on chemical quality of biscuits.

\begin{tabular}{|c|c|c|c|c|c|c|c|}
\hline Parameters & $\mathrm{P}_{1}$ & $\mathrm{P}_{2}$ & $\mathrm{P}_{3}$ & $\mathrm{P}_{4}$ & $\mathrm{P}_{5}$ & $\mathrm{P}_{6}$ & $\mathrm{P}_{7}$ \\
\hline Water content & $8.37 \pm$ & $8.32 \pm$ & $8.41 \pm$ & $8.66 \pm$ & $8.86 \pm$ & $8.53 \pm$ & $8.39 \pm$ \\
$(\%)$ & 0.41 & 0.29 & 0.41 & 0.14 & 0.16 & 0.41 & 0.31 \\
\hline Ash content & $1.26 \pm$ & $1.45 \pm$ & $1.43 \pm$ & $1.46 \pm$ & $1.43 \pm$ & $1.57 \pm$ & $1.26 \pm$ \\
$(\%)$ & $0.07^{\mathrm{b}, \mathrm{B}}$ & $0.12^{\mathrm{a}, \mathrm{AB}}$ & $0.01^{\mathrm{a}, \mathrm{AB}}$ & $0.06^{\mathrm{a}, \mathrm{AB}}$ & $0.12^{\mathrm{a}, \mathrm{AB}}$ & $0.03^{\mathrm{a}, \mathrm{A}}$ & $0.03^{\mathrm{b}, \mathrm{B}}$ \\
\hline Protein & $6.97 \pm$ & $10.50 \pm$ & $10.02 \pm$ & $10.03 \pm$ & $8.49 \pm 0.4$ & $4.39 \pm 0$. & $11.32 \pm$ \\
content(\%) & $0.28^{\mathrm{d}, \mathrm{D}}$ & $0.77^{\mathrm{b} . \mathrm{AB}}$ & $0.22^{\mathrm{b} . \mathrm{B}}$ & $0.72^{\mathrm{b} . \mathrm{B}}$ & $4^{\mathrm{c}, \mathrm{C}}$ & $08^{\mathrm{e}, \mathrm{E}}$ & $0.64^{\mathrm{a}, \mathrm{A}}$ \\
\hline Fat content & $24.07 \pm$ & $25.31 \pm$ & $24.93 \pm$ & $24.45 \pm$ & $23.69 \pm$ & $22.08 \pm$ & $22.16 \pm$ \\
$(\%)$ & $1.34^{\mathrm{a}, \mathrm{AB}}$ & $0.28^{\mathrm{a}, \mathrm{A}}$ & $0.67^{\mathrm{a}, \mathrm{A}}$ & $0.49^{\mathrm{a}, \mathrm{AB}}$ & $0.9^{\mathrm{b}, \mathrm{AB}}$ & $1.27^{\mathrm{b}, \mathrm{B}}$ & $1.44^{\mathrm{b}, \mathrm{B}}$ \\
\hline Carbohydrate & $59.32 \pm$ & $54.40 \pm$ & $55.21 \pm$ & $55.35 \pm$ & $57.50 \pm$ & $63.46 \pm$ & $56.86 \pm$ \\
content $(\%)$ & $1.56^{\mathrm{b}, \mathrm{B}}$ & $1.37^{\mathrm{d}, \mathrm{C}}$ & $0.46^{\mathrm{cd}, \mathrm{C}}$ & $1.37^{\mathrm{cd}, \mathrm{C}}$ & $0.27^{\mathrm{bc}, \mathrm{BC}}$ & $1.46^{\mathrm{a}, \mathrm{A}}$ & $1.73^{\mathrm{c}, \mathrm{BC}}$ \\
\hline Crude fiber & $3.22 \pm$ & $3.33 \pm$ & $3.38 \pm$ & $3.73 \pm$ & $4.12 \pm$ & $3.39 \pm$ & $2.18 \pm$ \\
content $(\%)$ & $0.49^{\mathrm{c}, \mathrm{BC}}$ & $0.11^{\mathrm{c}, \mathrm{B}}$ & $0.27^{\mathrm{bc}, \mathrm{B}}$ & $0.11^{\mathrm{b}, \mathrm{AB}}$ & $0.22^{\mathrm{a}, \mathrm{A}}$ & $0.38^{\mathrm{bc}, \mathrm{B}}$ & $0.11^{\mathrm{d}, \mathrm{C}}$ \\
\hline
\end{tabular}

Figures in table mean of 3 replicates \pm standard deviation. Numbers followed by different letters in the same column show significantly different effects at the $5 \%$ level (lowercase letter) and very significant differences at the $1 \%$ level (capital letter) with the LSR test.

Table 4 shows that the comparison of CF with OSPF on the moisture content of biscuits gave an insignificant different effect so that it was not continued to the LSR test.

Table 4 shows the comparison of CF with orange OSPF has a very significant effect $(\mathrm{P}<0.01)$ on the ash content of biscuits, where the highest ash content in treatment $\mathrm{P} 6$ $(100 \%$ OSPF) is $1.57 \%$ and The lowest ash content in the P1 treatment $(100 \% \mathrm{CF})$ was $1.26 \%$. This result is because in testing the quality of CF and OSPF, it is found that the ash content of OSPF is higher than CF so that it has an effect on the ash content of biscuit products. The relationship between flour ratio with biscuit ash content can be seen in Figure 4.

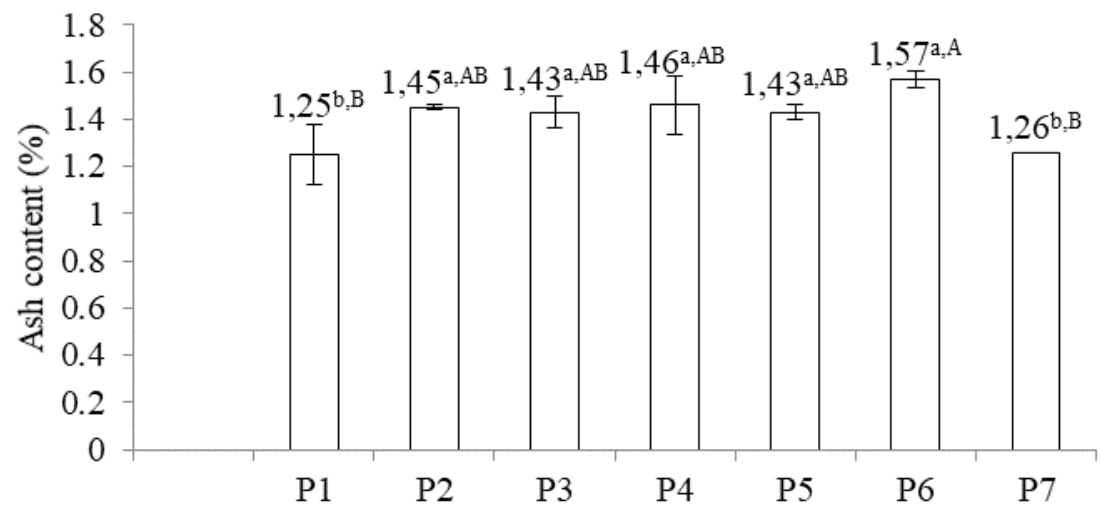

The comparison of CF with OSPF

Fig 4. The relationship between flour ratio with biscuit ash content

Table 4 shows the comparison of $\mathrm{CF}$ with OSPF has a very significant effect $(\mathrm{P}<0.01)$ on the protein content of biscuits, where the highest protein content in $\mathrm{P}_{7}$ biscuits $(100 \%$ 
WF) is $11.32 \%$ and the protein content is $11.32 \%$. the lowest was in $\mathrm{P}_{6}$ biscuit $(100 \%$ OSPF) which was $4.39 \%$ [13]. The relationship between flour ratio with biscuit protein content can be seen in Figure 5.

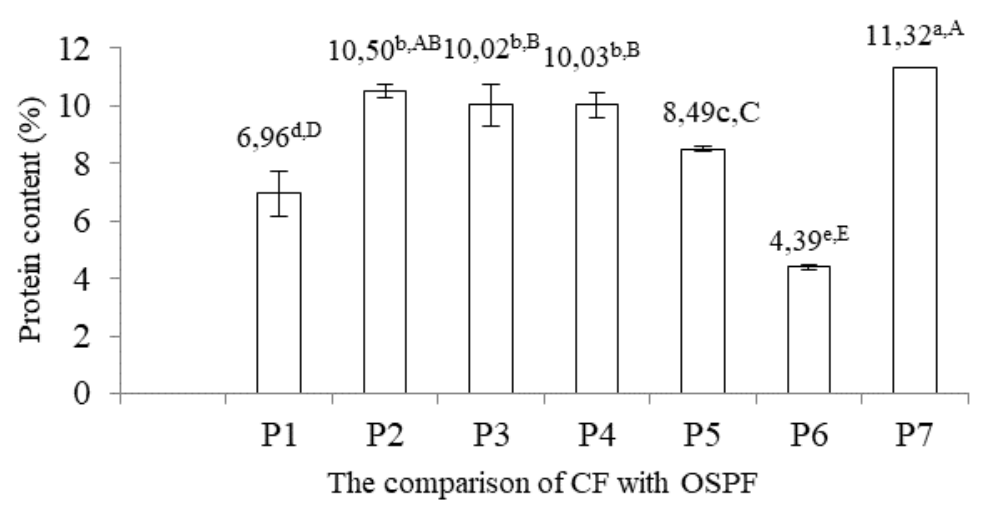

Figure 5. The relationship between flour ratio with biscuit protein content

Table 4 shows the comparison of CF with OSPF has a very significant effect $(\mathrm{P}<0.01)$ on the fat content of biscuits. This is because the fat content of CF and OSPF is different and there is the addition of $50 \mathrm{~g}$ of shortening in the manufacture of biscuit products [1416]. The relationship between flour ratio with biscuit water absorption can be seen in Figure 6.

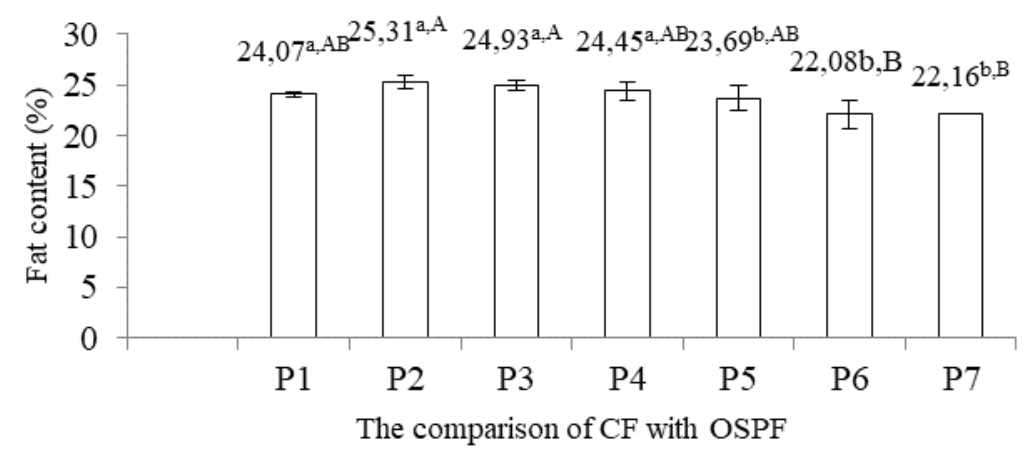

Fig 6. The relationship between flour ratio with biscuit fat content

Table 4 shows the comparison of CF with orange OSPF has a very significant effect $(\mathrm{P}<0.01)$ on the carbohydrate content of biscuits. From the results of the study, the highest carbohydrate content in $\mathrm{P}_{6}$ biscuit $\left(100 \%\right.$ OSPF) was $63.46 \%$ and the lowest was in $\mathrm{P}_{2}$ biscuit (80\% CF: $20 \%$ OSPF) which was $54.4 \%$ [17]. The relationship between flour ratio with biscuit carbohydrate content can be seen in Figure 7. 


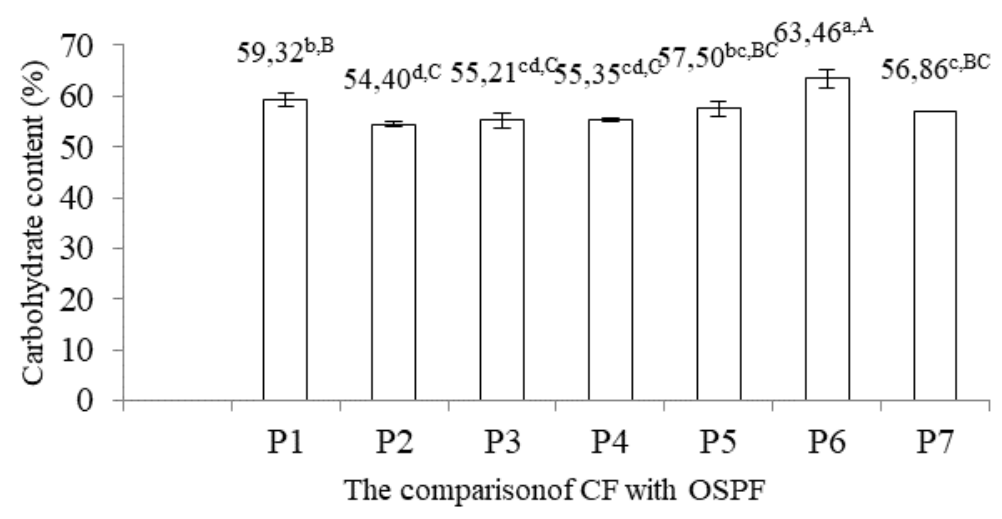

Fig 7. The relationship between flour ratio with biscuit carbohydrate content

Table 4 shows that the ratio of $\mathrm{CF}$ and $\mathrm{OSPF}$ has a very significant effect $(\mathrm{P}<0.01)$ on the crude fiber content of the biscuits. From the results of the biscuit research, it was found that the highest crude fiber content in $\mathrm{P}_{5}$ biscuits was $4.12 \%$. This result is because the results of the analysis of raw materials, namely CF has a lower fiber content $(3.58 \%)$ than the fiber content of OSPF (4.22\%), meaning the greater the addition of OSPF the higher the crude fiber content in biscuits. The relationship between flour ratio with biscuit crude fiber content can be seen in Figure 8.

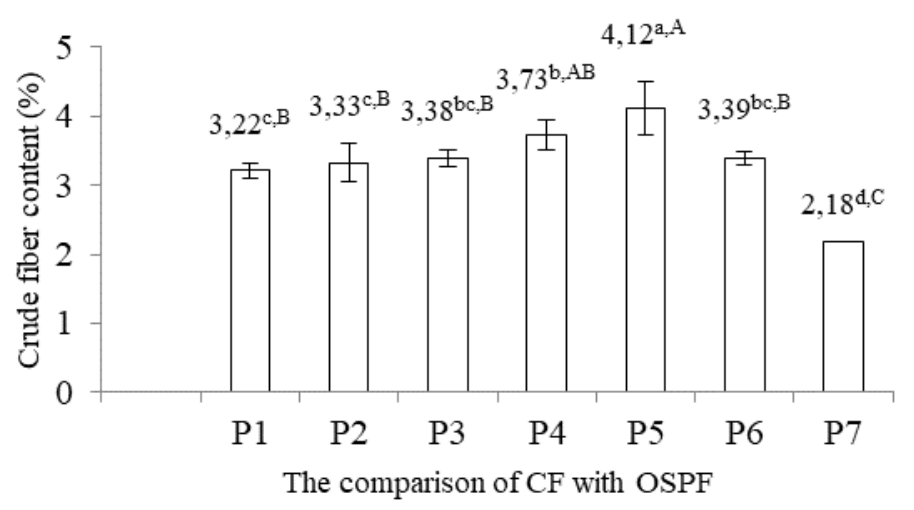

Fig 8. The relationship between flour ratio with biscuit crude fiber content

\subsection{Effect of blending ratio of CF and OSPF on sensory characteristics of biscuits}

The results showed that ratio of CF and OSPF had effect to sensory characteristics of biscuits as shown in Table 5 . 
Table 5. Effect of blending ratio of CF and OSPF on sensory characteristics of biscuits

\begin{tabular}{|c|c|c|c|c|c|}
\hline $\begin{array}{c}\text { Ratio of CF } \\
\text { and OSPF } \\
(\mathrm{P})\end{array}$ & Color & Aroma & Taste & Texture & $\begin{array}{c}\text { Overall } \\
\text { acceptability }\end{array}$ \\
\hline $\mathrm{P}_{1}$ & $5.75 \pm 0.16^{\mathrm{ab}}$ & $5.65 \pm 0.05^{\mathrm{b}, \mathrm{B}}$ & $5.71 \pm 0.05^{\mathrm{b}, \mathrm{B}}$ & $5.74 \pm 0.07^{\mathrm{b}, \mathrm{B}}$ & $5.80 \pm 0.08^{\mathrm{b}, \mathrm{B}}$ \\
\hline $\mathrm{P}_{2}$ & $5.76 \pm 0.17^{\mathrm{ab}}$ & $5.84 \pm 0.15^{\mathrm{b}, \mathrm{B}}$ & $5.72 \pm 0.05^{\mathrm{b}, \mathrm{B}}$ & $5.80 \pm 0.22^{\mathrm{b}, \mathrm{B}}$ & $5.86 \pm 0.08^{\mathrm{b}, \mathrm{B}}$ \\
\hline $\mathrm{P}_{3}$ & $5.52 \pm 0.45^{\mathrm{b}}$ & $5.78 \pm 0.03^{\mathrm{b}, \mathrm{B}}$ & $5.71 \pm 0.24^{\mathrm{b}, \mathrm{B}}$ & $5.80 \pm 0.08^{\mathrm{b}, \mathrm{B}}$ & $5.74 \pm 0.21^{\mathrm{b}, \mathrm{B}}$ \\
\hline $\mathrm{P}_{4}$ & $5.60 \pm 0.14^{\mathrm{b}}$ & $5.73 \pm 0.08^{\mathrm{b}, \mathrm{B}}$ & $5.69 \pm 0.17^{\mathrm{b}, \mathrm{B}}$ & $5.70 \pm 0.20^{\mathrm{b}, \mathrm{B}}$ & $5.77 \pm 0.09^{\mathrm{b}, \mathrm{B}}$ \\
\hline $\mathrm{P}_{5}$ & $5.51 \pm 0.42^{\mathrm{b}}$ & $5.67 \pm 0.11^{\mathrm{b}, \mathrm{B}}$ & $5.69 \pm 0.15^{\mathrm{b}, \mathrm{B}}$ & $5.66 \pm 0.10^{\mathrm{b}, \mathrm{B}}$ & $5.73 \pm 0.17^{\mathrm{b}, \mathrm{B}}$ \\
\hline $\mathrm{P}_{6}$ & $5.58 \pm 0.33^{\mathrm{b}}$ & $5.73 \pm 0.24^{\mathrm{b}, \mathrm{B}}$ & $5.77 \pm 0.17^{\mathrm{b}, \mathrm{B}}$ & $5.75 \pm 0.07^{\mathrm{b}, \mathrm{B}}$ & $5.81 \pm 0.20^{\mathrm{b}, \mathrm{B}}$ \\
\hline $\mathrm{P}_{7}$ & $5.47 \pm 0.36^{\mathrm{b}}$ & $5.70 \pm 0.13^{\mathrm{b}, \mathrm{B}}$ & $5.74 \pm 0.15^{\mathrm{b}, \mathrm{B}}$ & $5.88 \pm 0.28^{\mathrm{b}, \mathrm{B}}$ & $5.82 \pm 0.20^{\mathrm{b}, \mathrm{B}}$ \\
\hline Commercial $^{*}$ & $6.43 \pm 0.12^{\mathrm{a}}$ & $6.17 \pm 0.03^{\mathrm{a}, \mathrm{A}}$ & $6.22 \pm 0.13^{\mathrm{a}, \mathrm{A}}$ & $6.50 \pm 0.08^{\mathrm{a}, \mathrm{A}}$ & $6.31 \pm 0.15^{\mathrm{a}, \mathrm{A}}$ \\
\hline
\end{tabular}

Figures in table mean of 3 replicates, \pm standard deviation. Numbers followed by different letters in the same column show significantly different effects at the $5 \%$ level (lowercase letter) and very significant differences at the $1 \%$ level (capital letter) with the LSR test.

${ }^{*}$ Commercial product

From the data above, it can be seen that the highest color hedonic value is in P2 biscuits with a score of 5.76. Although the panelists gave a lower score than commercial biscuits, P2 biscuits had the highest score than P7 biscuits (100\% wheat flour). This is because the P2 biscuit ( $80 \%$ corn flour: $20 \%$ orange sweet potato flour) has a golden yellow color obtained from the beta-carotene pigment found in corn flour and orange sweet potato flour. While the color hedonic value with the lowest score is P7 biscuit (100\% wheat flour), this is because the color on P7 biscuit is much different from other biscuits because it only uses wheat flour so that the resulting color is pale white, therefore the panelists gave lower score. The relationship between flour ratio with the hedonic value of biscuit color can be seen in Figure 9.

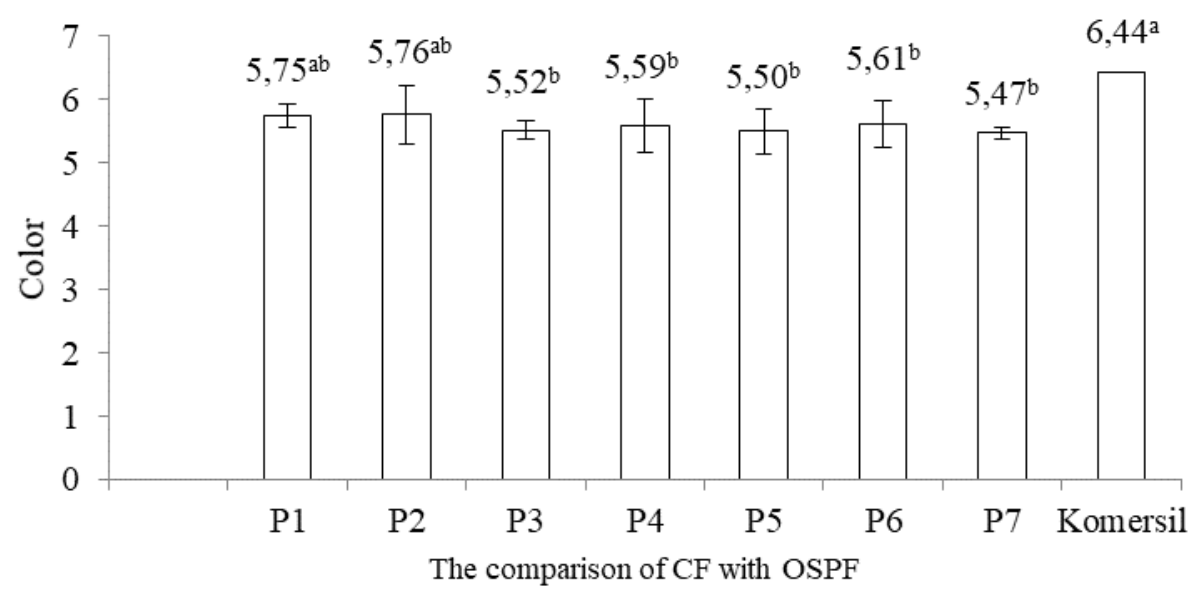

Fig 9. The relationship between flour ratio with the hedonic value of biscuit color

The data below shows that the highest hedonic aroma value is $\mathrm{P} 2$ biscuit $(80 \%$ corn flour: $20 \%$ orange sweet potato flour) with a score of 5.84. P2 biscuits were still lower than 
commercial biscuit scores, although P2 biscuits were not commercial products, panelists gave an assessment of the aroma of liking. This is because the panelists like the smell of corn mixed with a slight aroma of orange sweet potato ( $80 \%$ corn flour: $20 \%$ orange sweet potato flour) when compared to P1 biscuits (100\% corn flour) which has the lowest score of 5.65. The relationship between flour ratio with the hedonic value of biscuit aroma can be seen in Figure 10.

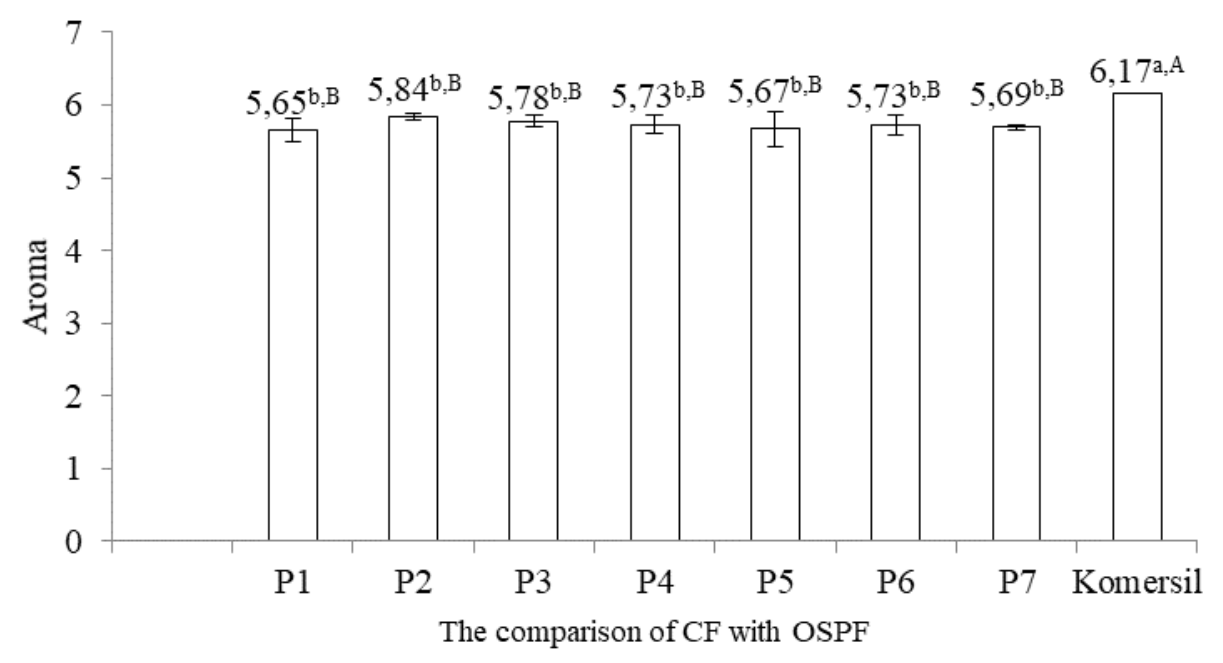

Fig 10. The relationship between flour ratio with the hedonic value of biscuit aroma

Based on the data below, it can be seen that the panelists gave an unsignificantly different score on the taste of the biscuits from corn flour with orange sweet potato flour, this is because the biscuits are made from raw materials of corn and orange sweet potato which are processed in the same way, resulting in biscuits. with a similar taste. According to Winarno [16], chemical compounds, temperature, and interactions with other flavor components can affect the taste of a food ingredient. The relationship between flour ratio with the hedonic value of biscuit aroma can be seen in Figure 11.

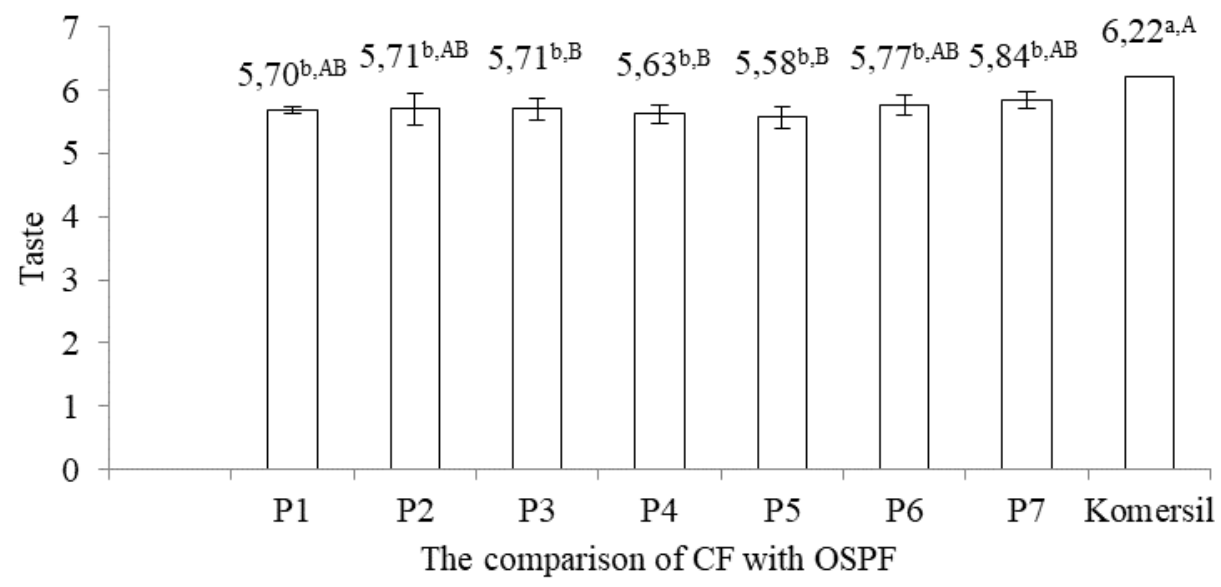

Fig 11. The relationship between flour ratio with the hedonic value of biscuit taste 
From the data below, it can be seen that the panelists gave a non-significantly different score on the texture of the biscuits from corn flour with orange sweet potato flour, this was because the biscuit texture of all biscuit treatments was crunchy, so the texture was quite liked by the panelists. According to Kusnandar [12], the crispness of a product is caused by the retrogradation process (amylose molecules bind to each other and bind to amylopectin molecules on the outside of the granule) during the baking of cooled biscuits. The relationship between flour ratio with the hedonic value of biscuit taste can be seen in Figure 12.

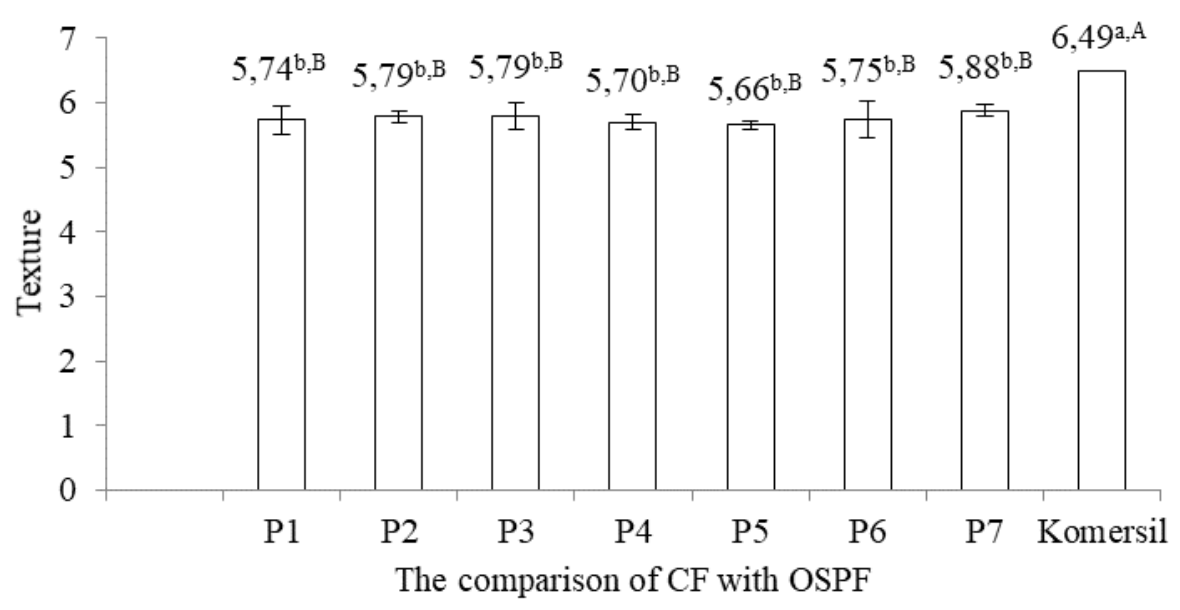

Fig 12. The relationship between flour ratio with the hedonic value of biscuit texture

Table 5 can be seen that the average of all hedonic values is 5 which means somewhat like so that the general acceptance hedonic value for biscuits from CF and OSPF is also somewhat like. The relationship between the effect of the comparison of CF with OSPF on overall acceptability of biscuit can be seen in Figure 13.

General acceptance relates to the hedonic values of color, aroma, taste, and texture. From the data above, it can be seen that the highest general acceptance value is in commercial products, but for each treatment P1 to P7, the general acceptance value is almost the same, namely 5 (slightly like) and the resulting notation also gives an insignificant difference. 


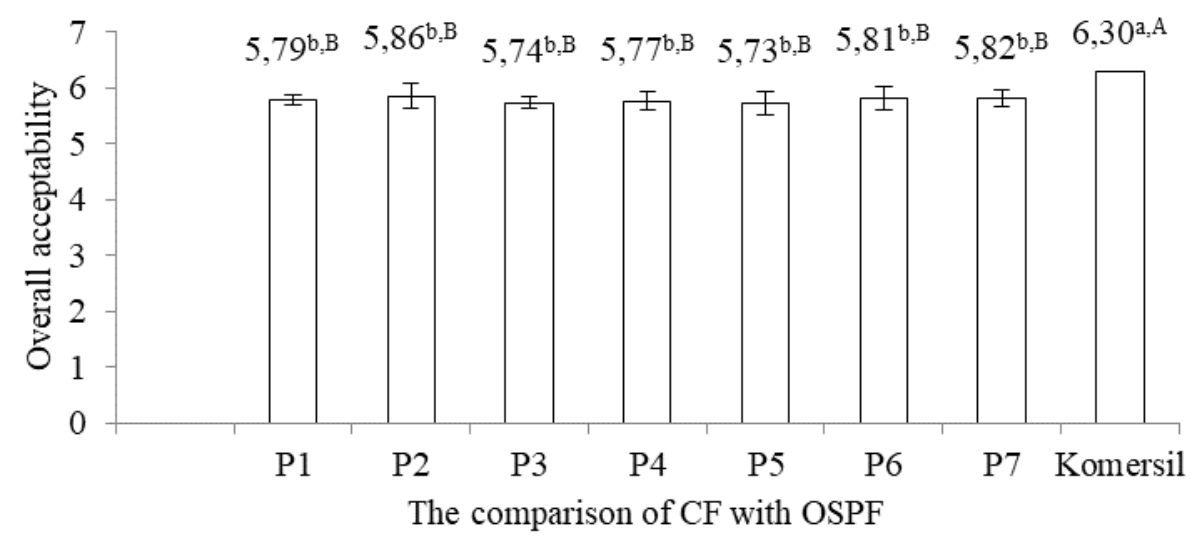

Fig 13. The relationship between flour ratio with overall acceptability of biscuit

\section{Conclusions}

The blending ratio of $\mathrm{CF}$ and OSPF has a very significant effect on the specific volume, hardness, water absorption, ash content, protein content, fat content, carbohydrate content, crude fiber content and hedonic value of biscuits. The results of the study concluded that the biscuits with the best physicochemical and sensory characteristics were $\mathrm{P}_{2}$ biscuits which were produced from $80 \% \mathrm{CF}$ and $20 \%$ OSPF.

\section{References}

[1] M. Istinganah, R. Rauf, E. N. Widyaningsih, J. K 10(2), 83-93 (2017)

[2] S, I. U. Firmansyah. Beras Jagung: Prosesing dan kandungan nutrisi sebagai bahan pangan pokok. Prosiding Seminar dan Lokakarya Nasional Jagung (Pusat Penelitian dan Pengembangan Tanaman Pangan, Bogor, 2005)

[3] A. Resmisari. Tepung jagung komposit, pembuatan dan pengolahannya. Prosiding Seminar Nasional Teknologi Inovatif Pascapanen Pengembangan Pertanian (Balai Besar Penelitian dan Pengembangan Pascapanen Pertanian, Bogor, 2006)

[4] R. ClaudiaR, T. Estiati. D. W. Ningtyas., E. Widyastuti, J. P A 1(4), 1589-1595 (2015)

[5] S. Limanto, E. Julianti, Z. Lubis, J. T I P 11(2), 64-68 (2019)

[6] A. P. Yananta., Perbaikan Proses Tepung Umbi Minor. Skripsi (Fakultas Teknologi Pertanian IPB, Bogor, 2003)

[7] Sathe, S. K. dan Salunkhe, D. K, J. F Sci 46,71-75 (1981)

[8] Analytical Chemist Publisher's Association. Official Techniques for Analyzing (AOAC Publisher, Washington DC, 1995)

[9] A. Apriyantono, D. Fardiaz, N. L. Puspitasari., Y. Sedarnawati, S. Budianto. Petunjuk Laboratorium Analisis Pangan (Pusat Antar IPB, Bogor, 1989)

[10] R. S. Igoe, Y. H. Hui., Dictionary of Food Ingredient, third edition (Chapman \& Hall. New York, 1996)

[11] Baik, Byung-K, Lee, Mee-R, J. C 80(3), 304-309 (2003) 
[12] Kusnandar, F. Kimia Pangan. Komponen Pangan (PT. Dian Rakyat. Jakarta, 2010)

[13] D. Sundari, Media Litbangkas. 25(4), 235-242 (2015)

[14] S. Ketaren. Pengantar Teknologi Minyak dan Lemak Pangan (UI-Press, Jakarta, 1986)

[15] A. D. Sediaoetama., Ilmu Gizi untuk Mahasiswa dan Profesi (Jakarta, 2008)

[16] F. G. Winarno., 2004. Kimia Pangan dan Gizi (PT. Gramedia, Jakarta, 2004)

[17] Sugito, A. Hayati, J. I P. 8(2), 147-151 (2006) 